\title{
Pharmaceutical Studies of Levothyroxine Sodium Hydrate Suppository Provided as a Hospital Preparation
}

\author{
Yuhei Hamada, ${ }^{a, \#}$ Kazushi Masuda,,${ }^{b, c, \#}$ Masato Okubo, ${ }^{b, c}$ Hiromitsu Nakasa, ${ }^{c}$ Yuko Sekine, ${ }^{b}$ and \\ Itsuko Ishii*,c,d \\ ${ }^{a}$ Department of Practical Pharmacy, Faculty of Pharmaceutical Sciences, Chiba University; 1-8-1 Inohana, Chuo- \\ ku, Chiba 260-8675, Japan: ${ }^{b}$ Department of Practical Pharmacy, Graduate School of Pharmaceutical Sciences, \\ Chiba University; 1-8-1 Inohana, Chuo-ku, Chiba 260-8675, Japan: ${ }^{c}$ Division of Pharmacy, University Hospital, \\ Chiba University School of Medicine; 1-8-1 Inohana, Chuo-ku, Chiba 260-8677, Japan: and ${ }^{d}$ Department of \\ Clinical Pharmacology, Graduate School of Pharmaceutical Sciences, Chiba University; 1-8-1 Inohana, Chuo-ku, \\ Chiba 260-8675, Japan.
}

Received October 14, 2014; accepted February 6, 2015

The levothyroxine sodium hydrate suppository ( $L-\mathrm{T}_{4}$-suppository) is provided as a hospital preparation for the treatment of hypothyroid patients with dysphagia in Japan because only oral preparations of levothyroxine sodium $\left(\mathrm{L}-\mathrm{T}_{4}\right)$ are approved for the treatment of hypothyroidism. However, it has been found that serum thyroxine and triiodothyronine levels do not increase as expected with the hospital preparation, requiring a higher dosage of $L-T_{4}$ in the $L-T_{4}$-suppository than in the oral preparations. In this study, to determine an effective thyroid gland hormone-replacement therapy for patients with dysphagia, the pharmaceutical properties of the $L-T_{4}$-suppository were investigated. Suppositories containing $300 \mu g$ L-T $_{4}$ in a base of Witepsol H-15 and Witepsol E-75 (ratio of 1:1) were prepared according to Chiba University Hospital's

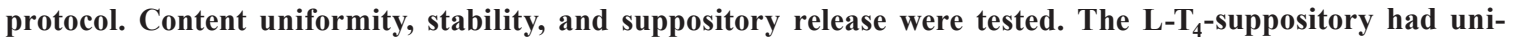
form weight and content. The content and release property were stable over $90 \mathrm{~d}$ when the $\mathrm{L}$ - $\mathrm{T}_{4}$-suppository was stored at $4^{\circ} \mathrm{C}$ and protected from light. The release rate of $\mathrm{L}-\mathrm{T}_{4}$ increased as $\mathrm{pH}$ increased. However, no $L-T_{4}$ was released below $\mathrm{pH}$ 7.2. The release rate of $\mathrm{L}-\mathrm{T}_{4}$ decreased as temperature decreased. These findings suggest that the low level of release of $L-T_{4}$ in the rectum under physiological conditions may be the cause of the low serum thyroxine and triiodothyronine levels following $L_{-} T_{4}$-suppository administration.

Key words levothyroxine sodium hydrate; suppository; hospital preparation; hypothyroidism; pharmaceutical study; thyroid gland hormone replacement therapy

Hypothyroidism is a state of insufficient function of the thyroid gland hormones thyroxine $\left(\mathrm{T}_{4}\right)$ and triiodothyronine $\left(\mathrm{T}_{3}\right)$, which results from either inadequate production of the hormones or their reduced action in target tissues. The prevalence of hypothyroidism has been reported to be between 0.6 and 12 per 1000 population in women and between 1.3 and 4.0 per 1000 population in men. ${ }^{1)}$ Untreated hypothyroidism can cause hypertension, dyslipidemia, infertility, cognitive impairment, and neuromuscular dysfunction. ${ }^{2)}$ Most patients with hypothyroidism will require lifelong thyroid gland hormone replacement therapy. $\mathrm{T}_{3}$ is the biologically active form, $80 \%$ of which is derived from the peripheral conversion of $\mathrm{T}_{4}$. Hypothyroidism is treated almost exclusively with once-daily synthetic $\mathrm{T}_{4}$ (levothyroxine sodium; $\mathrm{L}-\mathrm{T}_{4}$ ) preparations to control serum $\mathrm{T}_{4}$ and $\mathrm{T}_{3}$ levels.

In some cases, patients who are treated with thyroid gland hormone replacement therapy develop dysphagia because of surgery or other reasons and cannot continue with oral replacement therapy. Injections are approved for use in many countries but only oral preparations are approved in Japan. In these cases, the $\mathrm{L}_{-} \mathrm{T}_{4}$-hydrate suppository ( $\mathrm{L}-\mathrm{T}_{4}$-suppository) or $\mathrm{L}_{-} \mathrm{T}_{4}$-hydrate injection is used with consenting patients at Chiba University Hospital, Japan and with the hospital direc-

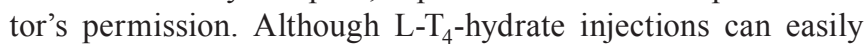
control serum $\mathrm{T}_{4}$ and $\mathrm{T}_{3}$ levels, the injections are associated with problems, restriction of activities and the need for vis-

\footnotetext{
\# These authors contributed equally to this work.

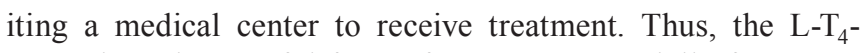
suppository is a useful form of treatment especially for outpatients. However, controlling serum $\mathrm{T}_{4}$ and $\mathrm{T}_{3}$ levels using the L- $\mathrm{T}_{4}$-suppository can be difficult: the levels do not increase as expected, and patients need higher dosages of $\mathrm{L}_{-} \mathrm{T}_{4}$ in the suppository to maintain optimal serum concentrations compared with oral preparations. The pharmaceutical properties, clinical effectiveness, or safety of the $\mathrm{L}_{-} \mathrm{T}_{4}$-suppository have

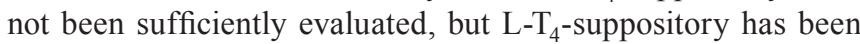
used empirically based on several case reports. ${ }^{3-7)}$ Therefore, in this study, we assessed the content uniformity, stability, and release property of the $\mathrm{L}_{-} \mathrm{T}_{4}$-suppository.

\section{MATERIALS AND METHODS}

Materials Thyradin $^{\circledR}-\mathrm{S}$ tablets $50 \mu \mathrm{g}$ (containing $50 \mu \mathrm{g}$ ${\mathrm{L}-\mathrm{T}_{4}}_{4}$ in the form of hydrates) were purchased from ASKA Pharmaceutical Co., Ltd. (Tokyo, Japan). 3,5-Diiodo-L-thyronine was purchased from Sigma-Aldrich Japan K.K. (Tokyo, Japan). Witepsol H-15, Witepsol E-75, and suppository mold $\left(2.25 \mathrm{~cm}^{3}\right)$ were purchased from Maruishi Pharmaceutical Co., Ltd. (Osaka, Japan). A syringe filter (hydrophilic polyolefin membrane, $0.45 \mu \mathrm{m}$ pore size) was purchased from GL Sciences Inc. (Tokyo, Japan). L-Thyroxine sodium salt pentahydrate and all other reagents used in this experiment were purchased from Wako Pure Chemical Industries, Ltd. (Osaka, Japan).

Preparation of the $\mathbf{L}-\mathbf{T}_{\mathbf{4}}$-Suppository Suppositories containing $300 \mu \mathrm{g} \mathrm{L}-\mathrm{T}_{4}$ were prepared by the fusion method 
Table 1. Composition of the $\mathrm{L}_{-} \mathrm{T}_{4}$-Suppository

\begin{tabular}{lc}
\hline \hline THYRADIN $^{\circledR}-\mathrm{S}$ TABLETS $50 \mu \mathrm{g}$ & 60 tablets \\
Witepsol H-15 & $8 \mathrm{~g}$ \\
Witepsol E-75 & $8 \mathrm{~g}$ \\
\hline
\end{tabular}

Ten suppositories (300 $\mu$ g L- $\mathrm{T}_{4} /$ suppository).

according to the hospital's protocol. A suppository base consisting of Witepsol H-15 and Witepsol E-75 (ratio of 1:1) was melted completely at $50^{\circ} \mathrm{C}$. Thyradin ${ }^{\circledR}$-S tablets were crushed in a mortar, and sifted through a 100 mesh sieve. The crushed powder was added to the melted base, and dispersed uniformly. The mixture was poured into a suppository mold and left at room temperature overnight to solidify. The obtained suppositories were stored at $4^{\circ} \mathrm{C}$ protected from light until use.

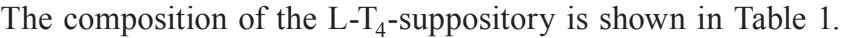

Analysis of ${\mathrm{L}-\mathrm{T}_{4}}_{4}$ by HPLC $\mathrm{L}-\mathrm{T}_{4}$ was measured by HPLC analysis using the internal standard method of Kato et al. with some modifications. ${ }^{8)}$ 3,5-Diiodo-L-thyronine was used as an internal standard. Internal standard solution was added to a sample (ratio of 1:9) and the mixture was subjected to HPLC analysis. The HPLC system was a SHISEIDO NANOSPACE SI-2 (Tokyo, Japan). The Inertsil ODS-3 $(4.6 \times 250 \mathrm{~mm}, 5 \mu \mathrm{m}$, GL Sciences Inc., Tokyo, Japan) column was used at $25^{\circ} \mathrm{C}$ with a flow rate of $900 \mu \mathrm{L} / \mathrm{min}$. ${\mathrm{L}-\mathrm{T}_{4}}_{4}$ was detected at a wavelength of $223 \mathrm{~nm}$, and the injection volume was $160 \mu \mathrm{L}$. The mobile phase was a solution of $0.1 \mathrm{~mol} / \mathrm{L} \mathrm{KH}_{2} \mathrm{PO}_{4}(\mathrm{pH} 3.0) /$ acetonitrile $(65: 35, \mathrm{v} / \mathrm{v})$; the $\mathrm{pH}$ of $0.1 \mathrm{~mol} / \mathrm{L} \mathrm{KH}_{2} \mathrm{PO}_{4}$ was adjusted to 3.0 using $\mathrm{H}_{3} \mathrm{PO}_{4}$. The peak area ratio of $\mathrm{L}-\mathrm{T}_{4} / 3,5$ diiodo-L-thyronine was calculated from the obtained chromatogram, and the concentration of ${\mathrm{L}-\mathrm{T}_{4}}_{4}$ was calculated from the calibration curve. The detection limit of this system was $0.02 \mu \mathrm{g} / \mathrm{mL}$.

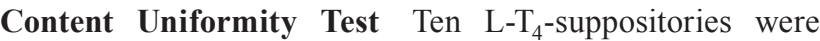
chosen randomly and their weight and $\mathrm{L}-\mathrm{T}_{4}$ content determined. A suppository was placed into a flask, $50 \mathrm{~mL} 0.1 \mathrm{~mol} / \mathrm{L}$ $\mathrm{NaOH}$ solution was added, and the flask was warmed at $50-60^{\circ} \mathrm{C}$ to melt completely. The suspension obtained was stirred and the flask cooled in ice for $2 \mathrm{~h}$ to solidify the base. After cooling, the suspension was filtered through filter paper to remove the base, and the filtrate was filtered again through a syringe filter. The sample obtained was analyzed by HPLC.

Stability Test Prepared L-T $_{4}$-suppository was stored under three conditions for $14,28,60$, and $90 \mathrm{~d}$ : (i) at $4^{\circ} \mathrm{C}$ protected from light, (ii) at room temperature protected from light, and (iii) at room temperature without protection from light. In keeping with standard environmental conditions, room lights were switched on for $15 \mathrm{~h}$ each day. After storage, the $\mathrm{L}_{-} \mathrm{T}_{4}$ content was determined in the same way as for the content uniformity test.

Suppository Release Test The suppository release test was carried out according to the reciprocating dialysis tube method with tapping using the dissolution apparatus HZ-21D (Miyamoto Riken Ind. Co., Ltd., Osaka, Japan). ${ }^{9)}$ Japan Pharmacopoeia (JP) distilled water $(\mathrm{pH} 5.8)$, the second fluid for the dissolution test $(\mathrm{pH}$ 6.9), Tris- $\mathrm{HCl}$ buffer solution $(\mathrm{pH} 7.2$, 8.2 , or 9.0 ), and $0.1 \mathrm{~mol} / \mathrm{L} \mathrm{NaOH}$ solution $(\mathrm{pH} 12.8$ ) were used as testing media.

The volume of the testing medium was $1000 \mathrm{~mL}$, and the test was carried out at $37.0 \pm 0.1^{\circ} \mathrm{C}$. Tests with $0.1 \mathrm{~mol} / \mathrm{L} \mathrm{NaOH}$
Table 2. Weight and L-T $\mathrm{T}_{4}$ Content of the $\mathrm{L}_{-} \mathrm{T}_{4}$-Suppository

\begin{tabular}{cccc}
\hline \hline Weight $(\mathrm{g})$ & $\mathrm{CV}(\%)$ & Content $(\mu \mathrm{g})$ & $\mathrm{CV}(\%)$ \\
\hline $2.06 \pm 0.07$ & 3.16 & $282.0 \pm 10.4$ & 3.70 \\
\hline
\end{tabular}

Each value represents the mean \pm S.D. $(n=10)$. CV: coefficient of variation.

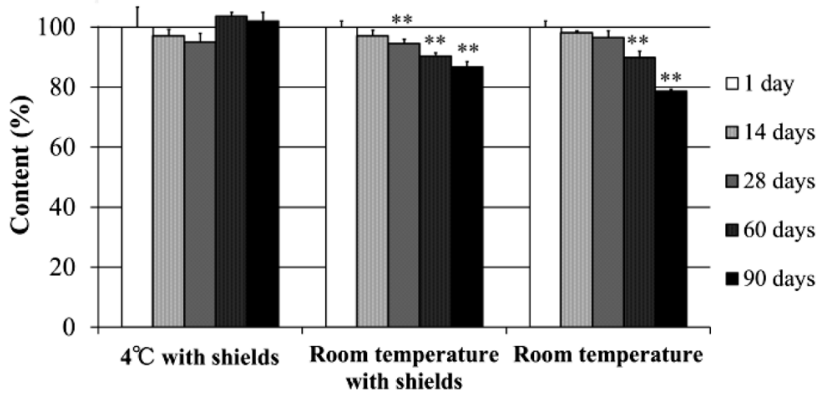

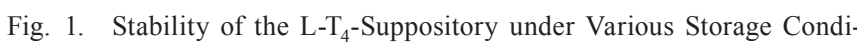
tions

Each value represents the mean \pm S.D. $(n=3) . * * p<0.01$ compared with day 1 in each group (Dunnett's test).

solution were also carried out at $35.0 \pm 0.1^{\circ} \mathrm{C}$ and $36.0 \pm 0.1^{\circ} \mathrm{C}$. The dialysis membrane (size 27 , length $21 \mathrm{~cm}$ ) was soaked in distilled water and rinsed before use. The arm of the apparatus moved up and down automatically at a constant speed (40 rpm). One milliliter of the buffer was sampled at each time point $(15,30,60,120,180$, and $240 \mathrm{~min})$, and $1 \mathrm{~mL}$ of fresh buffer was added to maintain the same volume. The sample was filtered through a syringe filter and analyzed by HPLC.

Statistical Analysis Data are presented as mean \pm standard deviation (S.D.). Statistical significance was analyzed using the Dunnett's test for multiple comparison, and Student's $t$-test for two-group comparisons. Differences at $p<0.05$ were considered statistically significant. All statistical analyses were conducted using StatLight 1997 software (Yukms Co., Ltd., Tokyo, Japan).

\section{RESULTS AND DISCUSSION}

Content Uniformity Test The weight and $\mathrm{L}_{-} \mathrm{T}_{4}$ content

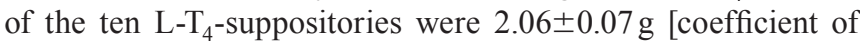
variation (CV) 3.16\%] and 282.0 $\pm 10.4 \mu \mathrm{g}$ (CV 3.70\%), respectively (Table 2). Content uniformity was checked by content uniformity test laid out in the JP 16th edition and it was confirmed to meet the JP criteria.

Stability Test When the L- $\mathrm{T}_{4}$-suppository was stored at $4^{\circ} \mathrm{C}$ protected from light, there was no significant decrease in $\mathrm{L}-\mathrm{T}_{4}$ content over the 90-d study period (Fig. 1). By contrast,

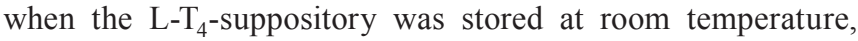

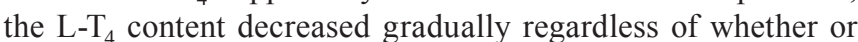
not the suppository was protected from light. The $\mathrm{L}-\mathrm{T}_{4}$ content decreased to about $87 \%$ and $79 \%$ in suppositories stored for $90 \mathrm{~d}$ with and without protection from light, respectively.

Thyradin ${ }^{\circledR}-\mathrm{S}$ tablets are reported to be stable for 36 months at $25^{\circ} \mathrm{C}$ and $60 \%$ relative humidity in press through package sheets protected from light, but Odani et al. reported that the $\mathrm{L}_{-} \mathrm{T}_{4}$ content of divided powders of crushed Thyradin ${ }^{\circledR}-\mathrm{S}$ tablets decreased when the powders were stored at room temperature regardless of protection from light..$^{10,11)}$ Our results 


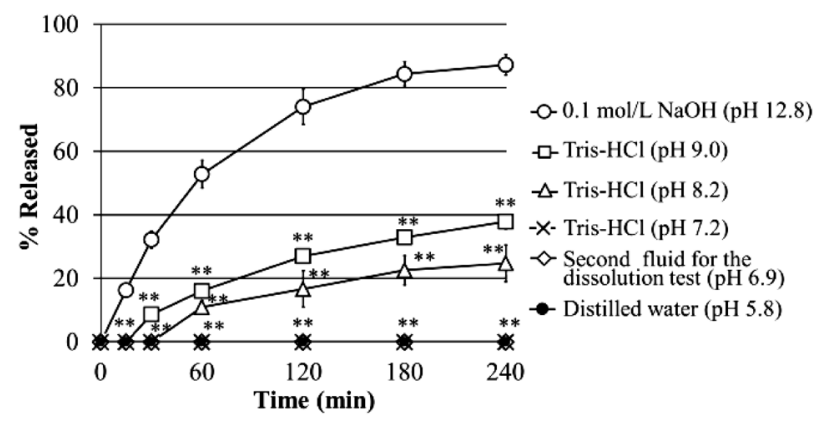

Fig. 2. Release Profiles of $\mathrm{L}_{-} \mathrm{T}_{4}$ from the $\mathrm{L}-\mathrm{T}_{4}-$ Suppository in Different $\mathrm{pH}$ Medium at $37^{\circ} \mathrm{C}$

Each point represents the mean \pm S.D. $(n=3)$. ${ }^{*} p<0.01$ compared with $0.1 \mathrm{~mol} / \mathrm{L}$ $\mathrm{NaOH}(\mathrm{pH} 12.8)$ at each time point (Dunnett's test).

support those of Odani et al. and suggest that the crushing of tablets may impair the stability of ${\mathrm{L}-\mathrm{T}_{4}}_{4}$ at room temperature. From these results, it appears that the $\mathrm{L}_{-} \mathrm{T}_{4}$-suppository should be stored at $4^{\circ} \mathrm{C}$ away from light to avoid a decrease in $\mathrm{L}_{-} \mathrm{T}_{4}$ content; under these conditions, drug content was confirmed to be stable for $90 \mathrm{~d}$.

Suppository Release Test The suppository release test was performed according to the reciprocating dialysis tube method with tapping. In the dialysis tube method, the suppository inside the membrane is in contact only with the testing medium through the membrane pores. By contrast, in the paddle method, the suppository is directly soaked in the testing medium. The dialysis tube method better simulates the physiological conditions given that there is only a small amount of fluid in the rectum and shows high reproducibility and in vitro-in vivo correlation in rabbits. ${ }^{9,12)}$

$\mathrm{L}-\mathrm{T}_{4}$ is very slightly soluble in water, and dissolves in dilute solutions of alkali hydroxides. Therefore, we used various solutions with different $\mathrm{pH}$ values, distilled water $(\mathrm{pH} 5.8)$, the second fluid for the dissolution test ( $\mathrm{pH}$ 6.9), Tris- $\mathrm{HCl}$ buffer

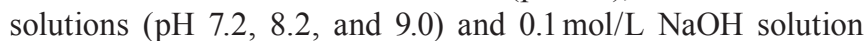
( $\mathrm{pH}$ 12.8) as testing media. Distilled water and the second fluid for the dissolution test are commonly used for dissolution tests of pharmaceutical preparations. More $\mathrm{L}_{-} \mathrm{T}_{4}$ was released as $\mathrm{pH}$ increased but ${\mathrm{L}-\mathrm{T}_{4}}_{4}$ was not released in $\mathrm{pH} 5.8, \mathrm{pH} 6.9$ and $\mathrm{pH} 7.2$ (Fig. 2). We could not confirm the release of ${\mathrm{L}-\mathrm{T}_{4}}_{4}$ because the amount dissolved was below the detection limit. $\mathrm{pH} 12.8$ showed the highest released percentage at every time point and about $87 \%$ of the total amount of $\mathrm{L}_{-} \mathrm{T}_{4}$ was released. The $\mathrm{pH}$ of rectal mucosa is reported to be within the range of 7.2 to $7.9 .{ }^{13,14)}$ The finding that no $\mathrm{L}^{-} \mathrm{T}_{4}$ was released below $\mathrm{pH} 7.2$ may explain the low serum $\mathrm{T}_{4}$ and $\mathrm{T}_{3}$ levels following $\mathrm{L}-\mathrm{T}_{4}$-suppository administration. The low release of $\mathrm{L}_{-} \mathrm{T}_{4}$ in the rectum under physiological conditions may result in the low degree of absorption and low serum levels.

Witepsol is a semi-synthetic oleaginous base and drug release from suppositories containing the oleaginous base is significantly affected by rectal temperature. Rectal temperature in healthy men varies from 36 to $37.5^{\circ} \mathrm{C}$ over the course of a day (high in the daytime and low in the nighttime). ${ }^{15}$ ) Thyroid hormones play an essential role in thermogenesis and hypothyroid patients tend to develop low body temperatures due to a reduction in thermogenesis. ${ }^{16)}$ We carried out the suppository release test at low temperatures $\left(35^{\circ} \mathrm{C}, 36^{\circ} \mathrm{C}\right)$ to investigate the effect of temperature on the release of $\mathrm{L}_{-} \mathrm{T}_{4}$.

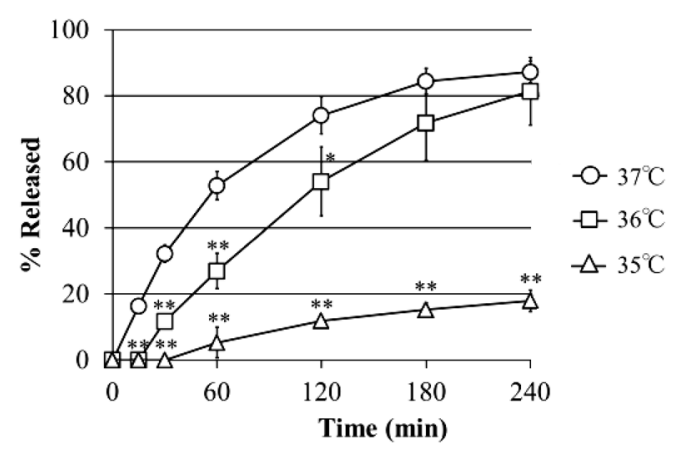

Fig. 3. Release Profiles of ${\mathrm{L}-\mathrm{T}_{4}}_{4}$ from the $\mathrm{L}-\mathrm{T}_{4}-$ Suppository in $0.1 \mathrm{~mol} / \mathrm{L}$ $\mathrm{NaOH}$ Solution at Different Temperatures

Each point represents the mean \pm S.D. $(n=3)$. $* p<0.05, * * p<0.01$ compared with $37^{\circ} \mathrm{C}$ at each time point (Dunnett's test).

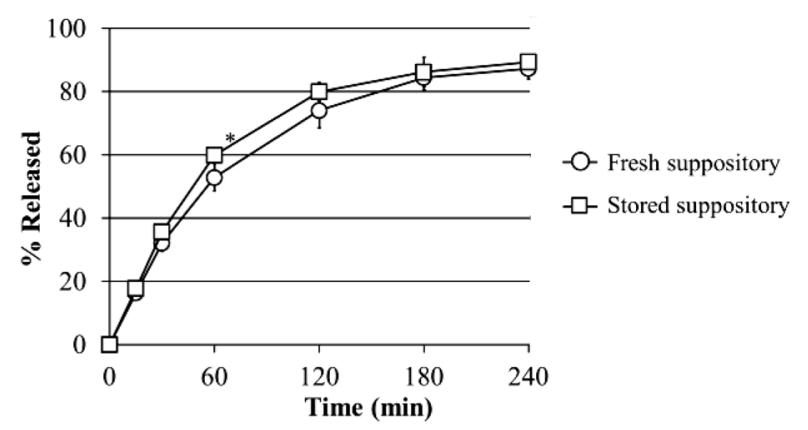

Fig. 4. Release Profile of ${\mathrm{L}-\mathrm{T}_{4}}_{4}$ from the $\mathrm{L}-\mathrm{T}_{4}-$ Suppository in $0.1 \mathrm{~mol} / \mathrm{L}$ $\mathrm{NaOH}$ Solution at $37^{\circ} \mathrm{C}$ after $90 \mathrm{~d}$ of Storage at $4^{\circ} \mathrm{C}$ Protected from Light

Each point represents the mean \pm S.D. $(n=3)$. ${ }^{*} p<0.05$ compared with fresh suppository at each time point (Student's $t$-test).

At $36^{\circ} \mathrm{C}$, which is the lowest normal body temperature, about $81 \%$ of $\mathrm{L}-\mathrm{T}_{4}$ was released within $240 \mathrm{~min}$ (Fig. 3). By contrast,

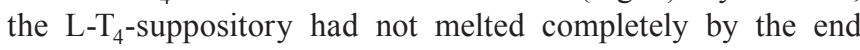
of the test at $35^{\circ} \mathrm{C}$ and only about $18 \%$ of $\mathrm{L}-\mathrm{T}_{4}$ was released. These results suggest that the efficacy of the $\mathrm{L}_{-} \mathrm{T}_{4}$-suppository might be reduced in hypothermic patients, compared to normothermic patients.

To investigate the effect of storage on the release of $\mathrm{L}_{-} \mathrm{T}_{4}$, the suppository release test was carried out after $90 \mathrm{~d}$ of storage at $4^{\circ} \mathrm{C}$ protected from light (Fig. 4). The release profile of the stored suppository was similar to that of the suppository within 1 week of preparation (fresh suppository). Although there was a significant difference at $60 \mathrm{~min}$, the released percentage was similar (approximately 60\% and 53\% for the stored and fresh suppository, respectively). This result suggests that the release properties of the $\mathrm{L}_{-} \mathrm{T}_{4}$-suppository did not change over the course of $90 \mathrm{~d}$ when stored at $4^{\circ} \mathrm{C}$ protected from light.

\section{CONCLUSION}

We confirmed that the $\mathrm{L}_{-} \mathrm{T}_{4}$-suppository had a uniform weight and $\mathrm{L}-\mathrm{T}_{4}$ content. The suppository's $\mathrm{L}-\mathrm{T}_{4}$ content and release property were stable for $90 \mathrm{~d}$ when stored at $4^{\circ} \mathrm{C}$ away from light.

The results of this study suggest clues to improve the re-

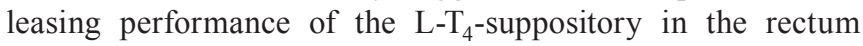
under physiological conditions. In the recent expansion in home healthcare, suppositories play an important role in medi- 


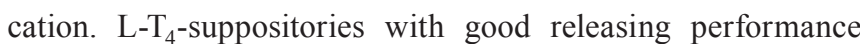
can be expected to provide a new route of administration for thyroid gland hormone replacement therapy and thereby improve patients' quality of life.

Conflict of Interest The authors declare no conflict of interest.

\section{REFERENCES}

1) Vanderpump MP. The epidemiology of thyroid disease. Br. Med. Bull., 99, 39-51 (2011).

2) Gaitonde DY, Rowley KD, Sweeney LB. Hypothyroidism: an update. Am. Fam. Physician, 86, 244-251 (2012).

3) Kurayoshi K, Kimura O, Toyoda N, Sakamoto H, Siota S, Yonekawa M, Hoshino K, Maeta M, Kaibara N. Report of a case with transrectal administration of thyroid hormone after total esophagectomy combined with thyroidectomy, parathyroidectomy and pharyngo-laryngectomy for cervical esophageal cancer. Jpn. J. Gastroenterol. Surg., 24, 856-860 (1991).

4) Shikama T, Abo S, Kitamura M, Hashimoto M, Itoh Y, Tanaka A, Satoh H, Shimada T. Report of an operated esophageal cancer case with transrectal administration of thyroid hormone after total thyroidectomy. Akita J. Med., 19, 421-428 (1992).

5) Takimoto $T$, Ito $M$, Kato $H$, Sasamoto $Y$, Nomura $T$. Transrectal administration of thyroid hormone after total laryngopharyngectomy and thyroidectomy. Practica Oto-Rhino-Laryngologica, 86, 103-108 (1993)

6) Matsushita $\mathrm{H}$, Isogai M, Kondo K, Fukunaga $\mathrm{Y}$, Kitamura N. Transrectal administration of thyroid hormone. J. Jpn. Surg. Assoc., 59, 2506-2508 (1998).

7) Nakajima Y, Takao N, Maekawa R, Terada S, Shiio Y, Ootani M,
Sugiura M, Yamamura Y, Uchino K. Utility of serum TSH monitoring in determining optimal dose of dried thyroid rectal suppositories. Jpn. J. Pharm. Health Care Sci., 37, 323-325 (2011).

8) Kato Y, Saito M, Koizumi H, Toyoda Y. Determination and stability of levothyroxine sodium injections prepared in hospital. Journal of the Nippon Hospital Pharmacists Association, 12, 253-256 (1986).

9) Itoh S, Teraoka N, Matsuda T, Okamoto K, Takagi T, Oo C, Danny Kao H. Reciprocating dialysis tube method: Periodic tapping improved in vitro release/dissolution testing of suppositories. Eur. J. Pharm. Biopharm., 64, 393-398 (2006).

10) ASKA Pharmaceutical Co. Ltd. “Thyradin ${ }^{\circledR}-S$ Tablets Interview Form. 9th ed.”: 〈http://www.aska-pharma.co.jp/eccube/html/upload/ save_file/if_thyradin_Stab_Spow_201210_09.pdf), cited 29 August, 2013.

11) Odani H, Sugioka N, Okada K, Ohta T, Kishimoto H. Stability and dispersibility of sodium levothyroxine in powder obtained by crushing tablet. Journal of the Nippon Hospital Pharmacists Association, 17, 448-453 (1991).

12) Yamazaki M, Itoh S, Sasaki N, Tanabe K, Uchiyama M. Modification of the dialysis membrane method for drug release from suppositories. Pharm. Res., 10, 927-929 (1993).

13) Yamazaki Y, Fukushima T, Kawamoto $M$, Sugita A, Suwa H, Tsuchiya S. Contact $\mathrm{pH}$ of rectal mucosa in patient with ulcerative colitis. Nihon Shokakibyo Gakkai Zasshi, 83, 165-169 (1986).

14) Bitterman W, Spencer RJ, Huizenga KA, Shorter RG. Contact $\mathrm{pH}$ of rectal mucosa in humans and dogs. Dis. Colon Rectum, 12, 96-98 (1969).

15) Honma K, Honma S, Kohsaka M, Fukuda N. Seasonal variation in the human circadian rhythm: dissociation between sleep and temperature rhythm. Am. J. Physiol., 262, R855-R891 (1992).

16) Silva JE. The thermogenic effect of thyroid hormone and its clinical implications. Ann. Intern. Med., 139, 205-213 (2003). 